\title{
An Assessment of Parallel Foreign Exchange Market as a Veritable Source of Low Income Residential Real Estate Development Finance in Enugu Urban Area, Nigeria (January - December, 2017)
}

\author{
Onwuka Nnenna Egbe1, Aniagolu Celestine Obinna², Iyi Edmund Amuezuoke ${ }^{3}$ \\ ${ }^{1} \mathrm{M} . \mathrm{Sc},{ }^{2,3} \mathrm{PhD}$ \\ 1,2Department of Estate Management, ${ }^{3}$ Department of Urban and Regional Planning, \\ 1, 2, 3 Enugu State University of Science and Technology, Enugu, Nigeria
}

\begin{abstract}
Sourcing real estate development finance remains one of most difficult problems facing real estate development in Nigeria. This paper therefore investigates the parallel foreign exchange market as a veritable source of low income residential real estate finance in Enugu, Nigeria. The study tries to determine the volume of transactions that took place in Enugu Parallel Foreign Exchange Market from January - December, 2017, to make projection upto 2022 and to determine the percentage of the transactions that could be made available to real estate development. Survey research method was adapted and data was collected through primary and secondary sources. The study reveals that the market has potential for raising between N6.837B and N12.23B within the period studied. Also about $34 \%$ of these funds could be made available for Real Estate Development finance in Enugu. Again the study shows that between 259 and 463 three bedrooms low income residential housing units could be raised from the Parallel Foreign Exchange Market annually. The study recommended among other things that the Nigerian Institution of Estate Surveyors and Valuers should embark on collaborative research aimed at understanding how real estate development finance could be raised and sustained through the parallel foreign exchange markets in Nigeria.
\end{abstract}

Keywords: Estate, Finance, Real Estate, Real Estate Finance, Market, Foreign Exchange, Foreign Exchange Market and Parallel Foreign Exchange Market

\section{Background of the Study}

According to Akbar (2016) the history of foreign exchange market (FEM) dates back to the biblical times although it was in the 1800s that formal Foreign Exchange Markets (FEMs) started developing. The need for formal FEMs arose from the need for countries to embark on international trade, hence FEMs assist international trade and investment by enabling currency conversion which are highly dependent on the value of the currencies of various countries involved. Oloye (2016) asserts that the value of a country's currency depends on a number of factors such as state of the economy, value and/or volume of exports, balance of trade and/or payment, level of domestic production, size of foreign reserves etc. According to him, the value of a currency in a free market economy could be determined to a great extent by the forces of demand and supply. Oladele (2012) pointed out that there is no currency that will be left completely to the forces of demand and supply. Consequently there must be some sorts of controls and regular interventions by the regulatory authorities.

In Nigeria the apex regulatory authority is currently the Central Bank of Nigeria (CBN). According to Soludo (2008) before the establishment of CBN in 1958 and the enactment of the Exchange Control Act of 1962, foreign exchange in Nigeria was earned by the private sector and was held by commercial banks who acted as agents to local exporters. At this time agricultural exports accounted for the bulk of foreign exchange and the fact that the Nigerian Pound (which was the currency in use at that time) was at par with the British Pound Sterling (which was very easy to convert) made the development of FEMs very slow in Nigeria.
Onwuka (2016) concluded that it was the discovery of crude oil, the increased export of same in the early 1970s, and the sharp increases in crude oil prices that enhanced the development of FEMs in Nigeria. It was not until 1982 that a comprehensive foreign exchange controls were applied.

In his own discussion, Alabi (2015) opined that the Nigerian Foreign Exchange Market is made up of three major segments namely, the official, the autonomous and the parallel markets. These according to Adekanye (2010) have evolved over time owing to the various stages of development of the Nigerian economy. Alabi (2015) further pointed out that since the introduction of exchange and trade liberalization policy in 1986, the official foreign exchange market has metamorphosized over the years. Oloye (2016) stated that between 1960 and 1986 Nigeria practiced fixed exchange rate system where the CBN administratively fixed the exchange rate. What followed after 1986 according to Oloyede (1999) was the introduction Second-Tier Foreign Exchange Market (SFEM) in 1986, the Autonomous Foreign Exchange Market (AFEM) in 1995, the Inter-Bank Foreign Exchange Market (IFEM) in 1999 and the Dutch Auction System (first in 1987, but was reintroduced) in 2002. Oloye (2016) summarized by stating that the CBN has in the past initiated strategic measures aimed at liberalizing the official foreign exchange market in Nigeria by ensuring increased supply of foreign exchange to all markets and by removing access bottlenecks to the official market. However, the parallel foreign exchange market has persisted. Oloyede (1999) stated clearly that the parallel foreign exchange market has been in existence in Nigeria from the 
exchange control era. Nnanna et al (2005) added that the numerous failed reforms to the official foreign exchange market, contributed in no small measure to the widening disparity in exchange rates and has further strengthened the Parallel Market due to the windfall gains arising therefrom. Nnanna et al (2005) therefore concluded that scarcity and bureaucratic bottlenecks in the official market has necessitated the growth of the parallel market since the market accommodates spillover demand from all sources. It is against this background that this paper tries to assess the possibility of raising real estate development finance in Enugu through the parallel foreign exchange market.

\section{Statement of the Problem}

According to Musa (2008), the parallel foreign exchange market in Nigeria has reached a highly remarkable size. Ayogu (1997) buttressed this by stating that the market apart from being ubiquitous can also be found in Kerbs, hotel lobbies, restaurants, airport lounges, outside parking lots, landings of staircases, under staircases, within commercial local markets, between floors of storied buildings, inside shacks in business bureaus, etc. Bobola (2009) concludes that any imaginable place where the parties involved feed secured during transaction automatically becomes a dealing spot.

Consequently, Oladele (2012) noted that over time, the parallel foreign exchange market has become a major source of foreign exchange market to a wide variety of economic agents and the exchange rate in the market is usually depreciated when compare with the official market. Hence, Ayodele and Obafemi (2010) further stated that it was the constant expansion of the parallel foreign exchange market that resulted in government losing control of the economy since more of foreign exchange meant for transactions in the official market are redirected to the parallel foreign exchange market. Caporale and Cerrato (2009) asserted that the difference between the official market rate and the Parallel Market rate is referred to as the "Black market premium". Oladele (2012) therefore continued by stating that the ratio of patronage of Parallel and Official Foreign Exchange Markets in Nigeria is 60\%: 40\%. This implies that if nothing is done about this problem, there is a possibility of up to $30.7 \%$ reduction in the number of customers patronizing banks for foreign exchange transactions.

Not minding the fact that the parallel market is an illegal market, the above analysis have shown that more transactions take place in the parallel market and there is no visible machinery set up by the government to eliminate or reduce to the barest minimum the activities of the parallel foreign exchange market.

According to Ibem, Anosike and Azuh (2011) one of the greatest challenges of real estate development in Nigeria is scarcity of housing finance. It is against this back drop that the researcher decided to assess the possibility of the parallel market being a veritable source of real estate finance in Enugu urban Area, Nigeria.

\section{Aim and Objectives of the Study}

The aim of this study is to assess the Parallel Foreign Exchange Market as a veritable source of Real Estate Development Finance in Enugu Urban Area, Nigeria. In order to achieve this aim, this research work intends to pursue the following line of objectives:

A. To determine the volume of transactions that take place in the Parallel Foreign Exchange Market in Enugu within January to December 2017.

B. To make projection on the expected level of transactions up-till 2022.

C. To determine the percentage of the funds that could be made available for low income residential real estate development from Enugu Parallel Foreign Exchange Market.

\section{Research Questions}

The following research questions were put forward:

A. What is the volume of transactions that take place in Enugu Parallel foreign exchange market?

B. What projection could be made up-till 2022?

C. What volume of funds could be made available for low income residential real estate development from Enugu Parallel Foreign Exchange Market?

\section{Scope of the Study}

This study covers the two major locations hosting parallel foreign exchange markets in Enugu namely - Okpara Avenue and Owerri Road (off Ogui Road). The study also concentrated on three major foreign currencies namely, Dollars, Pound Sterling and Euro. The purchase exchange rates were adopted for the study. Considerations were not giving to sales exchange rates. Again the study focuses on low income residential (three bedrooms bungalow) real estate development.

\section{The Study Area}

Enugu Capital of Enugu State, Nigeria is the study area. Its lies between latitudes $6^{\circ} 27^{\prime} \mathrm{N}$ and $7^{\circ} 28^{\prime} \mathrm{N}$ and longitudes 7०30`E and 8¹9`E (Enugu Master Plan, 1978). It has a total land area of about 72.8square kilometers. Its history dates back to 1909 when a rich seam of coal was discovered by some British geological exploration team (ENSG, 1991). The coal mining activities led to the development of the town and earned it the pet name "coal city" (Jibrum, 2012).

The 2006 population census put the population of Enugu at 722,664 people. If this figure is projected with the population growth rate of $3.18 \%$ per annum (NPC, 2014), then the population of Enugu as at 2018 should be close to $1,269,504$ people. 


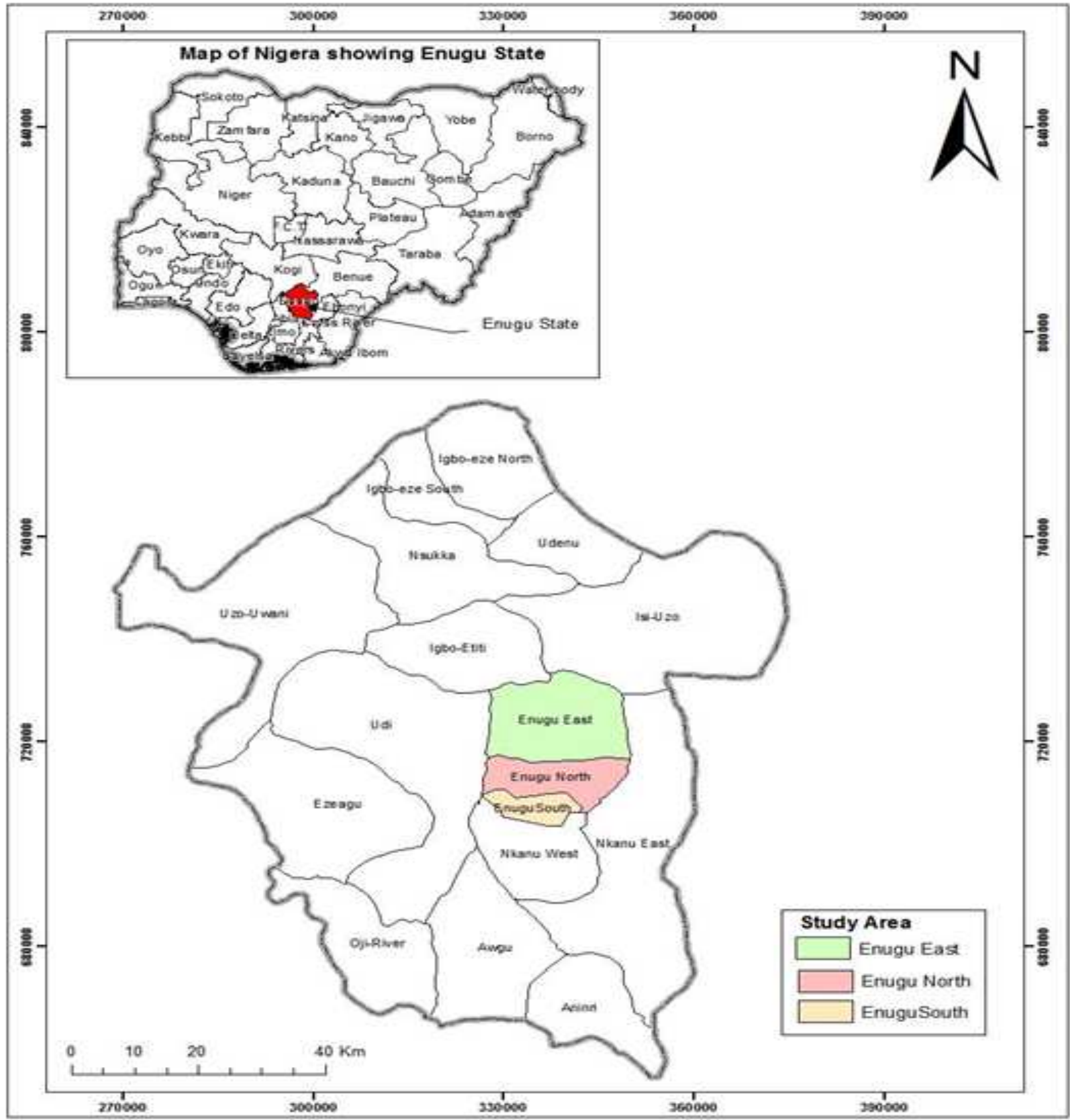

Map1: Map of Nigeria showing Enugu State

Source: https://www.researchgate.net/figure/Map-of-Nigeria-above-showingEnugu State-and-Map-of-Enugu-stateshowing-the-study-area_fig1_299822112

Enugu is predominantly occupied by Igbos who are widely known to be very resourceful and hard working. Enugu is covered with a secondary plant cover referred to as Savanna Mosaic-Forest since the primary forest cover has been depleted due to urban development, logging, agriculture and other human activities (Nwofor, 2003). According NIMET (2014) the town has a tropical wet and dry climate with annual rainfall figures ranging from $859 \mathrm{~mm}-1839 \mathrm{~mm}$ and average temperature at $28^{\circ} \mathrm{C}$.

\section{Materials and Methods}

Data required for this study was collected from both primary and secondary sources. The population of the study comprises the dealers (operators) in the parallel foreign exchange market at both Okpara Avenue and Owerri Road locations and customers (clients) who patronize the market. Also staff of CBN Enugu branch was used to crosscheck information generated. Again, staff of ministry of lands \& urban development and ministry of works \& housing Enugu also formed part of the population of the study. Members of Real Estate Development Association of Nigeria (REDAN) Enugu State Chapter equally forms part of the population of study.

The study adapted the survey research method which Kelinger (1973) emphasized that it studies sociological and psychological variables that teach people the vital facts about people and their beliefs, opinions, attributes, motivations and behavior through the use of sampling of the universe. Similarly, Nwabuokei (1986) further stated that survey research studies large population or universe by selecting and studying samples chosen from the population to discover the relative incidence, distribution and interrelationships of sociological variables 
International Journal of Trend in Scientific Research and Development (IJTSRD) @ www.ijtsrd.com eISSN: 2456-6470

8. Data Presentation and Analysis

8.1 Determination of Volume of Transaction in Enugu Parallel Market

In order to determine the volume of transactions in the study area, 5 (five) shops each were sampled at both Okpara Avenue and Owerri Road locations. Records of all transaction done in these shops were taken with the help of some field assistants for Jan - Dec. 2017. The records covered 24 (twenty-four) weeks and for each week transactions in the selected shops were recorded for seven day of the week since we observed that many operators were Moslems who do not observe the Sunday holidays. The weeks were alternated to ensure a wider coverage. The average transaction recorded in each of the 5 (five) shops in the two locations are presented in figures 1 and 2 .

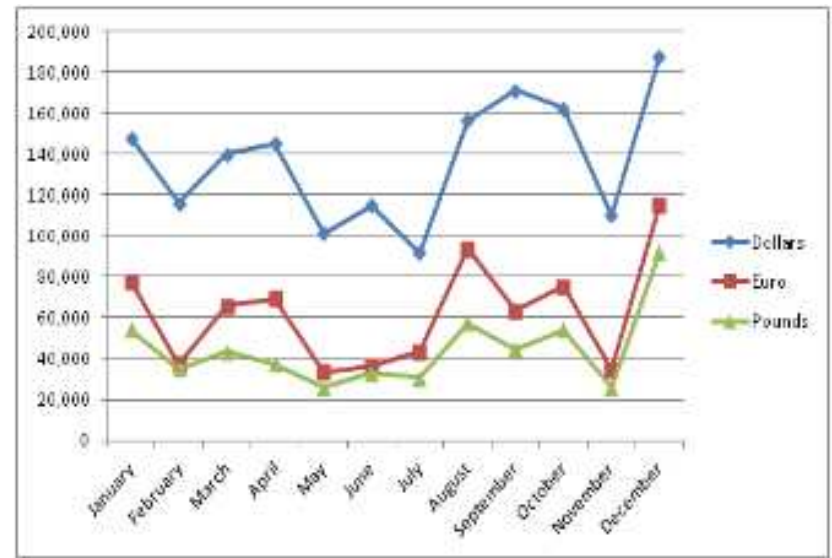

a. Shop 1 (Owerri Road)

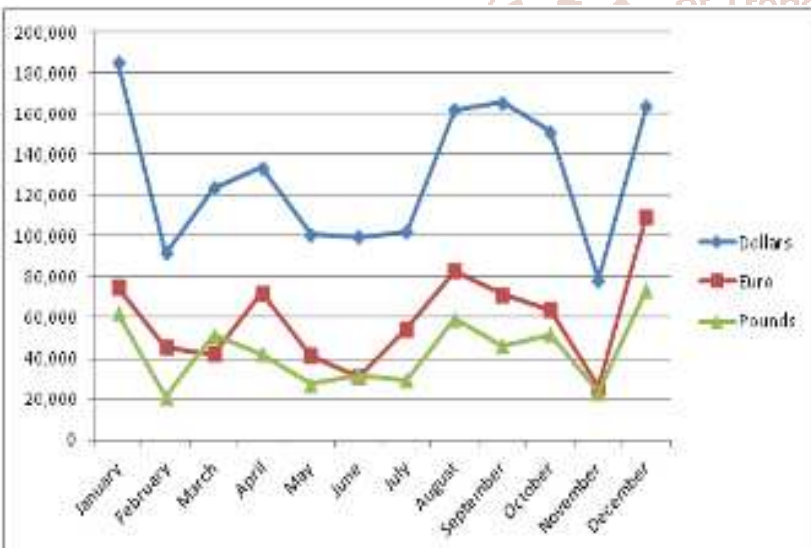

b. Shop 2 (Owerri Road)

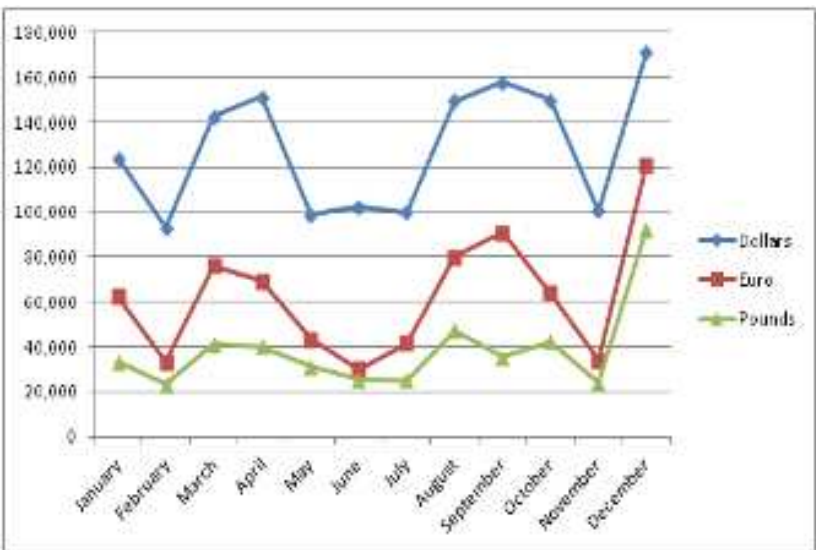

c. Shop 3 (Owerri Road)

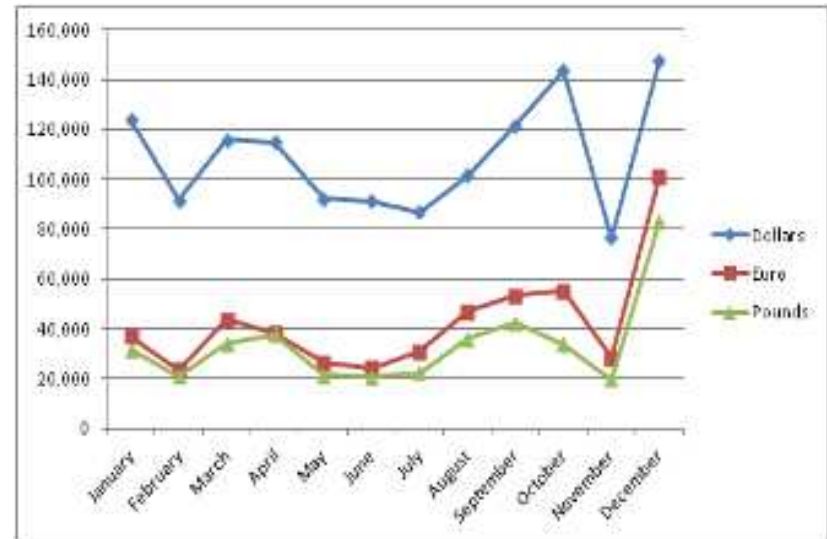

d. Shop 4 (Owerri Road)

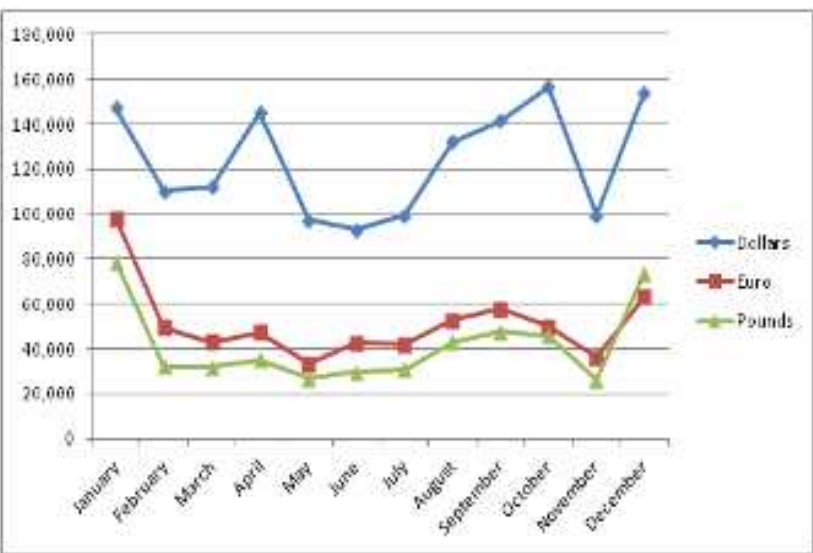

e. Shop 5 (Owerri Road)

Fig. 1: Showing the Average Volume of Transaction in

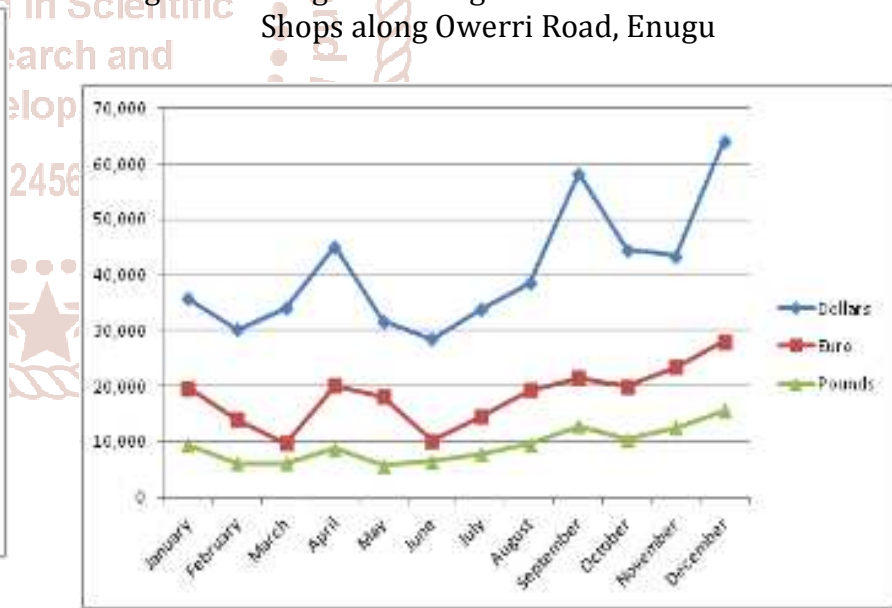

a. Shop 1 (Okpara Avenue)

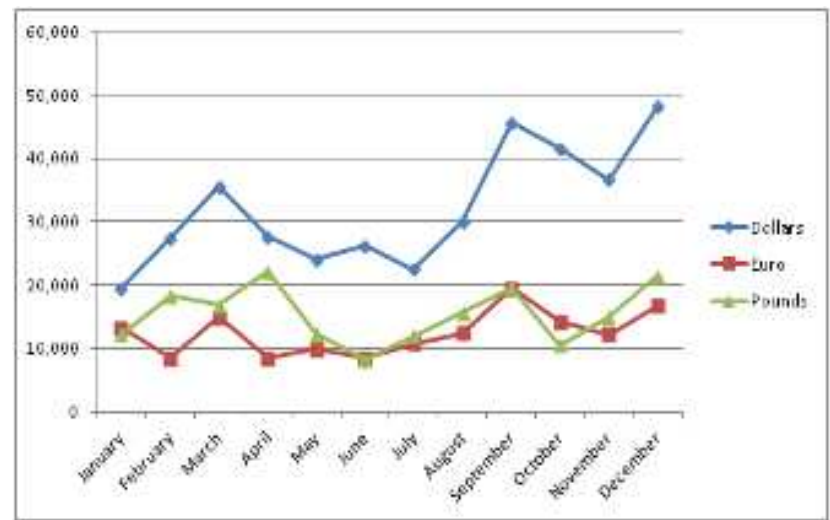

b. Shop 2 (Okpara Avenue) 
International Journal of Trend in Scientific Research and Development (IJTSRD) @ www.ijtsrd.com eISSN: 2456-6470

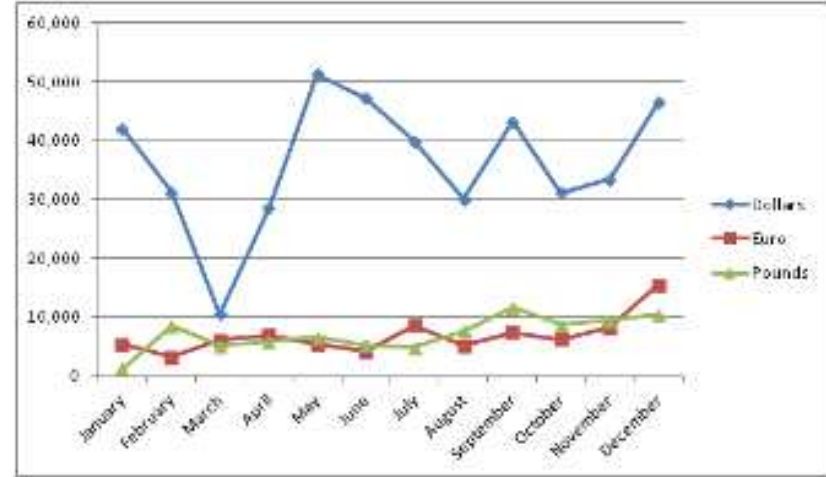

c. Shop 3 (Okpara Avenue)

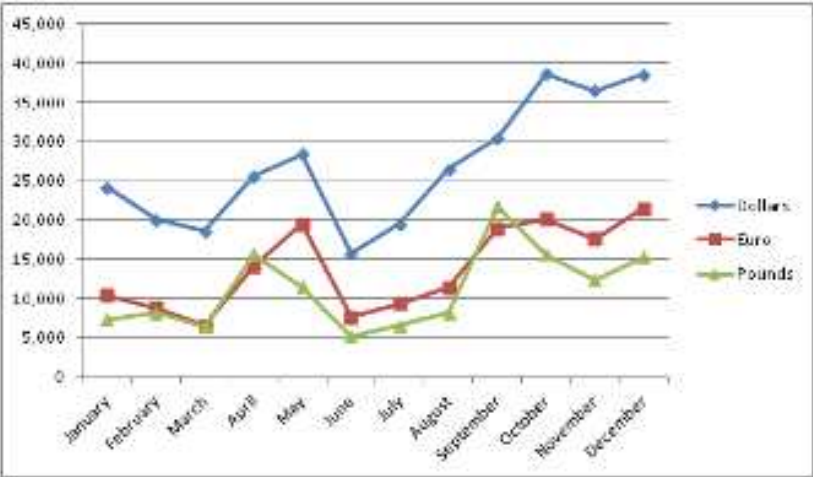

d. Shop 4 (Okpara Avenue)

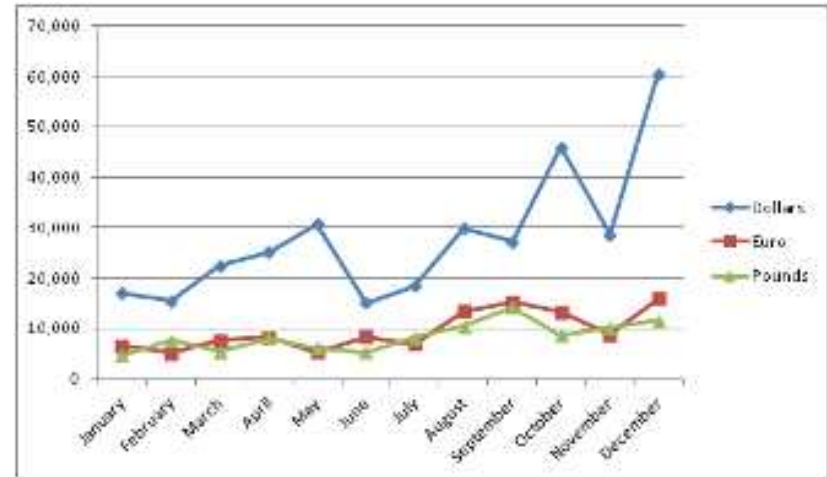

e. Shop 5 (Okpara Avenue)

Fig. 2: Showing the Average Volume of Transaction in Shops along Okpara Avenue, Enugu

From figures 1 and 2 it could be seen that the market at Owerri road is quite busy when compared with that of Okpara Avenue. Also most of the shops recorded maximum transactions within festivities in March/April and in November, December and January. Again high transactions were recorded in July, August, September and October representing periods of holidays and/or payment of school fees. The study equally observed that the major sources of this foreign exchange include western union transfers, domiciliary accounts and smuggling. The summary of the transactions is presented in table 1.

Table 1: Summary of Transactions in Selected Shops in Owerri Road and Okpara Avenue Enugu from January December, 2017.

\begin{tabular}{|c|c|c|c|c|c|c|}
\hline Shops & \multicolumn{3}{|c|}{ Owerri Road } & \multicolumn{3}{c|}{ Okpara Avenue } \\
\hline & $\begin{array}{c}\text { Dollars } \\
\$\end{array}$ & $\begin{array}{c}\text { Euro } \\
€\end{array}$ & $\begin{array}{c}\text { Pounds } \\
€\end{array}$ & $\begin{array}{c}\text { Dollars } \\
\$\end{array}$ & $\begin{array}{c}\text { Euro } \\
€\end{array}$ & $\begin{array}{c}\text { Pounds } \\
€\end{array}$ \\
\hline Shop1 & $1,644,814$ & 745,488 & 533,230 & 488,049 & 218,506 & 111,280 \\
\hline Shop 2 & $1,558,278$ & 725,056 & 520,371 & 384,879 & 149,365 & 184,170 \\
\hline Shop 3 & $1,540,222$ & 735,140 & 461,636 & 434,825 & 82,080 & 84,965 \\
\hline Shop 4 & $1,307,860$ & 867,922 & 403,113 & 322,450 & 165,795 & 133,700 \\
\hline Shop 5 & $1,488,626$ & 615,579 & 480,487 & 336,420 & 114,620 & 100,440 \\
\hline Total & $\mathbf{7 , 5 3 9 , 8 0 0}$ & $\mathbf{3 , 6 8 9 , 1 8 5}$ & $\mathbf{2 , 3 9 8 , 8 3 7}$ & $\mathbf{1 , 9 6 6 , 6 2 3}$ & $\mathbf{7 3 0 , 0 0 0}$ & $\mathbf{6 1 4 , 5 5 5}$ \\
\hline
\end{tabular}

Source: Field work, 2017

Dollars $=\$ 9,506,423$

Euro $=€ 4,419,185$

Pounds $=£ 3,133,395$

Table 1 vividly summarized the transactions in the 10 shops sampled. It shows the total amount of Dollars, Euro and Pounds that were bought by the operators in the market. The final figures as recorded include $\mathbf{\$ 9 , 5 0 6 , 4 2 3}$ (Dollars), $€ 4, \mathbf{4 1 9 , 1 8 5}$ (Euro) and $£ \mathbf{3 , 1 3 3 , 3 9 5}$ (Pounds) from January - December, 2017.

\subsection{Projection for the Volume of Transaction for the Next five Years (Up-till 2022).}

Five years projection was made using the final figures in table 1. Nigerian inflation growth rate was obtained from https://www.statista.com for 2018. Since that is the last recorded rate, it was used to make projections for 2018 - 2022 . Table 2 presents the projections made.

Table 2 Projection for Expected Volume of Transaction in Enugu from 2018 - 2022 Using CBN Inflation Growth Rate

\begin{tabular}{|c|c|c|c|c|c|c|}
\hline Currency & 2017 & $2018(12.4 \%)$ & $2019(12.4 \%)$ & $2020(12.4 \%)$ & $2021(12.4 \%)$ & $2022(12.4 \%)$ \\
\hline Dollars (\$) & $9,506,428$ & $10,684,101$ & $12,008,930$ & $13,498,037$ & $15,171,793$ & $17,053,096$ \\
\hline Euro (€) & $4,419,185$ & $4,967,164$ & $5,583,093$ & $6,275,396$ & $7,053,545$ & $7,928,184$ \\
\hline Pounds (£) & $3,133,395$ & $3,521,936$ & $3,958,656$ & $4,449,529$ & $5,001,271$ & $5,621,429$ \\
\hline
\end{tabular}

Table 2 shows the projected transactions in the study area for the period $2018-2022$. It could be seen that using 2018 inflation growth rate which CBN put at $12.4 \%$ the projected transaction for Dollars in 2022 is $\mathbf{\$ 1 7 , 0 5 2 , 0 9 6}$ while that of Euro and Pounds sterling are $€ \mathbf{€ 7 , 9 2 8 , 1 8 4}$ and $\mathbf{€ 5 , 6 2 1 , 4 2 9}$ respectively. 
International Journal of Trend in Scientific Research and Development (IJTSRD) @ www.ijtsrd.com eISSN: 2456-6470

\subsection{Conversion of the Currencies to Naira Using the Average Exchange Rate for 2017/2018}

The average monthly exchange rates in the black market for August 2017 - December, 2018 was obtained from NAIJAQUEST.COM. The website gave the minimum and maximum parallel market exchange rates for the specified months. The average for each month was determined and the result was used to determine the average exchange rates for Dollar, Euro and Pounds for the entire period. The results were then used to convert the currencies in table 2 to Naira. The result is presented in table 3.

Table 3: Conversion of currencies to Naira Using the Average Parallel Market Rate for 2017/2018

\begin{tabular}{|c|c|c|c|c|c|c|c|c|c|c|}
\hline \multirow{2}{*}{$\begin{array}{l}\text { Ye } \\
\text { ar }\end{array}$} & \multicolumn{3}{|c|}{ Dollars Avenue } & \multicolumn{3}{|c|}{ Euro Avenue } & \multicolumn{3}{|c|}{ Pounds Avenue } & \multirow[t]{2}{*}{ Total } \\
\hline & $\begin{array}{c}\text { Dollars } \\
\$\end{array}$ & $\begin{array}{l}\text { Excha } \\
\text { nge } \\
\text { Rate } \\
\end{array}$ & $\begin{array}{c}\text { Naira } \\
\text { Equivalen } \\
\mathrm{t} \\
\end{array}$ & $\begin{array}{c}\text { Euro } \\
€\end{array}$ & $\begin{array}{l}\text { Excha } \\
\text { nge } \\
\text { Rate }\end{array}$ & $\begin{array}{c}\text { Naira } \\
\text { Equivalen } \\
t\end{array}$ & $\begin{array}{c}\text { Pound } \\
\text { s } \\
f\end{array}$ & $\begin{array}{c}\text { Excha } \\
\text { nge } \\
\text { Rate }\end{array}$ & $\begin{array}{c}\text { Naira } \\
\text { Equivalen } \\
t\end{array}$ & \\
\hline $\begin{array}{l}20 \\
17\end{array}$ & $\begin{array}{c}9,506,4 \\
28\end{array}$ & 361.7 & $\begin{array}{c}3,438,475 \\
008\end{array}$ & $\begin{array}{c}4,419,1 \\
85\end{array}$ & 424 & $\begin{array}{c}1,893,734 \\
440\end{array}$ & $\begin{array}{c}3,133,3 \\
95\end{array}$ & 480.5 & $\begin{array}{c}1,505,596 \\
298\end{array}$ & $\begin{array}{c}6,837,805 \\
746\end{array}$ \\
\hline $\begin{array}{l}20 \\
18\end{array}$ & $\begin{array}{c}10,684 \\
101\end{array}$ & 361.7 & $\begin{array}{c}3,864,439 \\
332\end{array}$ & $\begin{array}{c}4,967,1 \\
64\end{array}$ & 424 & $\begin{array}{c}2,106,077 \\
536\end{array}$ & $\begin{array}{c}3,521,9 \\
36\end{array}$ & 480.5 & $\begin{array}{c}1,692,290 \\
248\end{array}$ & $\begin{array}{c}7,662,807, \\
116\end{array}$ \\
\hline $\begin{array}{l}20 \\
19\end{array}$ & $\begin{array}{c}12,008 \\
930\end{array}$ & 361.7 & $\begin{array}{c}4,343,629 \\
981\end{array}$ & $\begin{array}{c}5,583,0 \\
93\end{array}$ & 424 & $\begin{array}{c}2,367,231 \\
432\end{array}$ & $\begin{array}{c}3,958,6 \\
56\end{array}$ & 480.5 & $\begin{array}{c}1,902,134 \\
208\end{array}$ & $\begin{array}{c}8,612,995, \\
621\end{array}$ \\
\hline $\begin{array}{l}20 \\
20\end{array}$ & $\begin{array}{c}13,498 \\
037\end{array}$ & 361.7 & $\begin{array}{c}4,882,239 \\
983\end{array}$ & $\begin{array}{c}6,275,3 \\
96\end{array}$ & 424 & $\begin{array}{c}2,660,767 \\
904\end{array}$ & $\begin{array}{c}4,449,5 \\
29\end{array}$ & 480.5 & $\begin{array}{c}2,137,998 \\
685\end{array}$ & $\begin{array}{c}9,681,006, \\
572\end{array}$ \\
\hline $\begin{array}{l}20 \\
21\end{array}$ & $\begin{array}{c}15,171 \\
793\end{array}$ & 361.7 & $\begin{array}{c}5,487,637 \\
528\end{array}$ & $\begin{array}{c}7,053,5 \\
45\end{array}$ & 424 & $\begin{array}{c}2,990,703 \\
080\end{array}$ & $\begin{array}{c}5,001,2 \\
71\end{array}$ & 480.5 & $\begin{array}{c}2,403,110 \\
716\end{array}$ & $\begin{array}{c}10,881,145 \\
, 132\end{array}$ \\
\hline $\begin{array}{l}20 \\
22\end{array}$ & $\begin{array}{c}17,053 \\
096\end{array}$ & 361.7 & $\begin{array}{c}6,168,104 \\
823\end{array}$ & $\begin{array}{c}7,928,1 \\
84\end{array}$ & 424 & $\begin{array}{c}3,361,550 \\
016\end{array}$ & $\begin{array}{c}5,621,4 \\
29\end{array}$ & 480.5 & $\begin{array}{c}2,701,096 \\
635\end{array}$ & $\begin{array}{c}12,230,751 \\
470\end{array}$ \\
\hline
\end{tabular}

The result from table 3 shows that the transactions that took place within Enugu Parallel foreign Exchange market is quite formidable ranging from $\$ 6.837 \mathrm{~B}$ in 2017 and $\$ 12.330 \mathrm{~B}$ as projected to 2022 . This shows that the parallel foreign exchange market in Enugu is not a market that should be wished away by any well meaning government.

\subsection{Determine of the Number of Low Income Housing Units that could Be Financed through the Enugu Parallel Market}

Questionnaires were distributed to customers / clients who patronized the Parallel Market during the period of study. One of the questions posed in the questionnaire helped us to determine the percentage of the amount that was exchanged which the clients were interested in investing into real estate. The average stood at $34 \%$.

Again, questionnaires were distributed to members of REDAN and staff of Ministry of Works and Housing. The questionnaire tried to determine the current cost of constructing a modest 3 bedrooms bungalow in various locations in Enugu. Value of land was not taken into consideration in the analysis. The study reveals that a modest 3 bedroom bungalow in Enugu will cost about $\$ 9,000,000$ (Nine Million Naira) to construct, with these available information, table 4 tries to determine the number of housing units that could be developed from funds generated from the parallel market.

Table 4 Determination of the Number of Housing Units that could be Financed Through the Enugu Parallel Market

\begin{tabular}{|c|c|c|c|c|c|}
\hline Year & $\begin{array}{l}\text { Total Amount of } \\
\text { Foreign Exchange } \\
(\mathrm{f})\end{array}$ & $\begin{array}{l}\text { Dedicated for } \\
\text { Real Estate } \\
\text { Development }\end{array}$ & $\begin{array}{l}\text { Amount Dedicated for } \\
\text { Real Estate Development } \\
\text { (N) }(34 \%)\end{array}$ & $\begin{array}{c}\text { Cost of Construction } \\
\text { of a } 3 \text { Bedrooms } \\
\text { Bungalow }(\mathrm{N})\end{array}$ & $\begin{array}{l}\text { No. of } \\
\text { Bungalow } \\
\text { Per Year }\end{array}$ \\
\hline 2017 & $6,837,805,746$ & 34 & $\mathrm{~N} 2,324,853,954$ & $\mathrm{~N} 9,000,000$ & 259 \\
\hline 2018 & $7,662,807,116$ & 34 & $2,605,354,419$ & $\mathrm{~N} 9,000,000$ & 290 \\
\hline 2019 & $8,612,995,621$ & 34 & $2,928,418,511$ & $\mathrm{~N} 9,000,000$ & 326 \\
\hline 2020 & $9,681,006,572$ & 34 & $3,291,542,234$ & $\mathrm{~N} 9,000,000$ & 366 \\
\hline 2021 & $10,881,145,132$ & 34 & $3,641,589,344$ & $\mathrm{~N} 9,000,000$ & 412 \\
\hline 2022 & $12,230,751,470$ & 34 & $4,158,455,500$ & $\mathrm{N9}, 000,000$ & 463 \\
\hline
\end{tabular}

Table 4 clearly shows that it is possible to raise real estate development finance from the parallel foreign exchange market. It could be seen from the analysis that in 2017, about 259 housing units came directly or indirectly from the market. Five years projection from that figure shows an arithmetic progression from 259 in 2017 to 463 in 2022 . Taking into consideration the fact that the study covered neither all the shops in the study area, nor the entire 52 weeks of the year, the result is a pointer that the parallel foreign exchange market if properly harnessed could be a formidable source of real estate development finance in Nigeria. 


\section{Recommendations}

The Nigerian economy is currently be-devilled with quite a number of problems ranging from over-dependence on oil and gas revenue, import oriented economy, instability in government policies, high illiteracy level, corruption, very high population growth rate and imbalance in demand and supply of foreign exchange currencies to mention only but a few. These problems have adversely affected many other sectors of the economy including the real estate industry since real estate development depend so much on the availability of funds. It become necessary therefore that alternative source of real estate development finance should be explored for sustainability. This work therefore recommend as follows: firstly, government at all levels in Nigeria should recognize the amorphous nature of the parallel foreign exchange market in Nigeria. This will in turn trigger off inquiry into how the potentials of the market can be harnessed. Secondly, extensive research should be carried out by the government to understand the dynamics of the parallel foreign exchange market. Thirdly, the Nigeria Institution of Estate Surveyors and Valuers (NIESV) should play a leadership role by also embarking on collaborative research with academic departments in Nigerian Universities aimed at understanding how real estate development finance could be sourced through the parallel foreign exchange market. Fourthly, the various researches if properly done would generate policies that could help in making sure that all the transactions in the parallel foreign exchange market are properly recorded. This will in turn remove the illegality of the parallel market with time. Finally, government should vigorously pursue policies that would revitalize the Nigeria economy and reduce our overdependence on importation.

\section{Conclusion}

The parallel foreign exchange market in Nigeria has become a major source of foreign exchange to many. Infact, the rate of patronage of the market outweighs that of the official market due to documentation bottlenecks, administrative costs and other charges, better exchange rates, limited transactions, etc. experienced in the official market. The potentials of the market should therefore be harnessed for better financing of other sectors of the Nigeria economy. This paper therefore demonstrates that if properly harnessed, the parallel foreign exchange market in Nigeria could turn out to be a very good source of real estate finance in Nigeria.

\section{Reference}

[1] Adekanye, F. (2010): Elements of Banking in Nigeria. F and A Publishers Limited, Lagos, Nigeria.

[2] Akbar, M. I. (2016): Efficiency of Foreign Exchange Markets: The Case for Nigeria. Journal of Global Economics, Vol. 4, Issue 4, 2016.

[3] Alabi, R. O. (2015): Foreign Exchange Market and the Nigerian Economy. Journal of Economics and Sustainable Development. Vol. 6, No. 4, 2015 www.iiste.org

[4] Ayodele, O. S. and Obafemi, F. N. (2010): Fiscal and Quasi-Fiscal Effects of the Parallel Exchange Premium in Nigeria. AERC Research Papers, Pp 3.

[5] Ayogu, M. D. (1997): “Empirical Studies of Nigeria's Foreign Exchange Parallel Market II: Speculative Efficiency and Noisy Trading". AERC Research Papers Series, Research Paper Sixty-Nine, Pp 4 and 5.
[6] Bobola, C. M. (2009): Factors Enhancing the Growth of "Black Markets for Foreign Exchange in Nigeria". An Unpublished MBA Dissertation; Lagos State University, Ojo, Lagos.

[7] Caporale, G. M. and Cerrato, M. (2009): Black Market and official exchange rates: Long-run equilibrium and short-run dynamics centre for International Capital Markets, London Metropolitan- University.

[8] Enugu Metropolitan Master plan (1978) phase 2, prepared by concept Ecodesign International, Enugu.

[9] ENSG (1991): "Welcome to Enugu State". A Publication of Enugu State Tourism Board.

[10] Ibem, E.O., Anosike, M.N. and Azuh, D. E. (2011): Challenges in Public Housing Provision in the Post Independence Era in Nigeria. International of Humon Sciences, Vol. 8, Issue 2, 2011.

[11] Jibururm, U . (2002) "Mode Using Urban Residential water demand in Enugu and Owerri". An unpublished Ph.d Thesis, Department Of Urban of Regional Planning, University of Nigeria, Enugu Campus.

[12] Musa, M. (2008): "Empirical Regularities in the Behaviour of Exchange Rates and Theories of the Foreign Exchange Market". Carnegie-Rochester Conference Series on Public Policy 11:9 - 57.

[13] National Population Commission, NPC (2014): Census figure projected to 2014, Official Gazette, Enugu.

[14] Nigeria Meteorological Agency (NIMET) (2014): Seasonal Rainfall Prediction, March 2014, Pp $38-42$.

[15] Nwafor, J. C. (2003): "Profile of Enugu State" Paper Presented during a Workshop on Strategy and Policy Development for Sustainable Environment, Held at Presidential Hotel, Enugu

[16] Nnanna et al (2005): Financial Markets in Nigeria. A Publication of Central Bank of Nigeria (CBN).

[17] Oladele, P. O. (2012): Foreign Exchange Transaction in Nigeria: Determinants of Customers Preferences for Banks and Black Market Patronage. The Journal of Commerce. Vol. 4, No.2.

[18] Oloye, M. I. (2016): Foreign Exchange Management in Nigeria: the Journey So Far. Pyrex Journal of Business and Finance Management Research, Vol. 2 (2), Pp 012 016, February, 2016.

[19] Oloyede, B. (1999): Principles of Money and Banking. Fortright Publications, Lagos, Nigeria.

[20] Onwuka, N. E. (2016): Analysis of the Impact of Parallel Foreign Exchange Market on Real Estate Development in Enugu Metropolis from January - December, 2014. Unpublished M.Sc Dissertation, Department of Estate Management, Enugu State University of Science and Technology, Enugu.

[21] Soludo, C. C. (2008): “Exchange Rate Misalignment and Investment in Nigeria" Being a Paper Presented to OECD Development Centre, Paris. 